\title{
Equality and Difference in Education. Theoretical and Practical Issues in Equity Education - A Polish Example
}

\author{
Eva Zamojska \\ Adam Mickiewicz University in Poznań, Faculty of Educational Studies
}

Received $30^{\text {th }}$ September 2016 / final version received $9^{\text {th }}$ February 2017 / accepted $11^{\text {th }}$ February 2017

\begin{abstract}
The purpose of this paper is to reflect on the contemporary understanding of equality and differences in education and to present key theoretical and practical issues affecting equity education in Poland based on a selection of studies by various authors. Each equity education project must face the dialectics of equality and difference in education. In a longer historical perspective, the evolution of the modernist concept of equality in education is clearly seen. The essence of this evolution was the changing perception of difference: from understanding equality as sameness and emphasis on standardized educational practices (comprehensive school) (although subject to the national idea - Gellner - and to hidden gender, class, race, ethnic divisions), through segregation and selection on the grounds of various distinctions of difference, over to the contemporary understanding of equality as acceptance of differences and striving for an equilibrium between sensitivity to differences and equal treatment of everyone irrespectively of those differences. This third understanding of the dialectics of equality and difference creates the basis for equity education, which the author considers to be one of the means of social inclusion. Three key obstacles to effective implementation of this idea need to be highlighted. Firstly, it is the field of education (Bourdieu) and its specific nature. The need to transform people in line with preset goals, testing and the hierarchical structure of the very process of education is rather difficult to align with the stated understanding of equality. Another serious problem is the neoliberal market logic which deepens class divisions within the very structure of the educational system (i.e. the division into private and public schools) and creates internal differences among public schools ("better" and "worse" schools), thus imposing rivalry and extreme individualization (or indeed a cultural capital contest) on all participants of the field of education in their pursuance of their goals. The third problem involves the non-alignment of the content of curriculum and textbooks with the assumptions of the equity discourse. This problem will be illustrated with an example from Poland with references to this and other authors' research into textbook content.
\end{abstract}

Keywords: equality, difference, equity education 
This paper sets out to define the contemporary understanding of equity in education and to determine whether and how it is implemented in common schools and how it is critically analyzed. On the one hand, this paper reflects my research interest in the contemporary equity discourse in education; on the other, it draws from my practical experience in teaching an equity education course at Adam Mickiewicz University in Poznań, Poland. A reflection on equity discourse in education should answer the question about the presence and understanding of the idea of equity in common schools - in school curricula and handbooks, in how education is organized, in classroom communication, etc. A diagnosis of the condition of equity education should also serve the purpose of its separation from the related contemporary educational concepts based on the idea of equity, such as inclusive education and anti-discrimination education. Since education, including equity education, is linked to state policy and cultural tradition of the society, I believe that it is important also to determine which social factors can be considered as obstacles to implementing the idea of equity in education.

Here, equity is considered as one of the fundamental organizational principles of contemporary democratic societies. It is a political principle - all citizens have equal rights and are equal before the law; it is also a principle of social relations - all individuals, irrespective of their personal characteristics, must be treated equally; finally, it is a moral principle - all people are equal in their human dignity, have the right to be respected, no-one may be treated instrumentally. In social practice, these abstract ideas clash with cultural hierarchies (often considered to be natural) maintained by tradition, custom or prejudice: citizens have equal rights, but should a child have all the rights of an adult? Men and women are not equal for natural (biological) reasons; must a criminal's (i.e. a terrorist's) dignity be respected? Such problems imply questions about the universality of the equity principle, about its functional limitations due to historical and cultural conditions and about the conflict between the value of equity and other general values, such as freedom or safety. In this paper, I only briefly point out to these problems in order to emphasize the fundamental contextuality of how equity is understood by and functions in the society. I am primarily interested in the functioning of equity in the very field of education. I use the notion of "field of education" as a term linked to P. Bourdieu's social theory (Bourdieu, 2001) in order to stress relative functional autonomy and its own internal logic which - 
according to L. Kopciewicz - "not only determines the nature of belonging and activities possible in this area, but first of all is a space of possibility for innovative actions of teachers involved in it" (2007, p. 75). Therefore, I am interested in equity in school curricula - in school handbooks and syllabi, in teacher-to-student communication and interaction, as well as in various forms of organizing formal education. Is equity (understood as a principle of social organization and also as a principle of interpersonal relations) themed? Is it present in school texts, in how education is organized, in classroom communication and interactions?

\section{Theoretical and methodological assumptions}

The theoretical and methodological foundations of this article are formed by social constructivism which accommodates the notion of discourse. I make references to two discourse concepts. According to Foucault, the notion of discourse refers to "a historically conditioned system of meanings determining the identity of subjects and objects" (Foucault 2002, as quoted by Howarth 2008, p. 24). "A discourse is a set of rules that prescribe what can be said and how" (Stasiuk, 2003, p. 126), i.e. it includes rules requiring silence, imposed and prescribed by power relation. Foucault's famous powerknowledge metaphor means that no knowledge is innocent (objective) and all knowledge is bound by power relations and cultural context.

In their turn, Laclau and Mouffe, in their definition of discourse as a system of meanings, emphasize that "meaning attributed to objects and actions is formed as part of systems consisting of considerable differences" (Laclau \& Mouffe, 2007, as quoted by Howarth, 2008, p. 158). In other words, different meanings can be attributed to the same object or action at the same time, thus creating different discursive structures. "Created meanings are always non-final, which follows from the 'openness of the social'. In its turn, this openness derives from the fact that 'each discourse is established as an attempt at conquering the discursive field, containing free flow of differences, creating a kind of a center'." (Laclau \& Mouffe, 2007, as quoted by Howarth, 2008, p. 159).

Therefore, I understand the notion of discourse as capturing the social world in language and by language. What it means is that although the social world possesses real existence outside our will, for us it exists only in language, discourse and meanings that we ascribe to it. Discourse is a condition for 
sustaining power; however, as it is formed in opposition to other discourses, it never conquers the semantic field in a total and absolute manner. This certain unclosedness of discourse - each discourse - creates a space for competitive discourses and thus for creating an alternative system of identities and social relations. Equity discourse competes with hierarchical or elitist discourses. Rather than concentrate on their confrontation, I wish to present equity discourse as a certain complete entity that evolves over time.

\section{Reflecting equity and difference in contemporary education}

The thesis I wish to propose is that equity discourse (i.e. the way equity is understood and discussed) keeps changing, which should also be reflected in a change in educational discourse on equity. Generally, the essence of this change is the change in addressing difference.

The idea of equity in social life has always been connected to a certain attitude towards difference (or diversity) and has never been easily implemented in practice. Savater, when describing the emergence of the idea of equity in the society of Greek polis, called it a revolutionary and subversive idea, because it contradicted the prevailing perception of the human world as a world of differences (diversities). It was not merely a political idea, but also a cognitive challenge and - in the long term - a moral challenge as well. Savater puts it this way:

Diversity of life is a richness consisting of differences between genders, races, tastes, talents. We do not want to live without it, but we would not like to change it into a source of hierarchies condemning some people to debilitating poverty, ignorance or lack of civil rights. The continuing dispute between the balance of what we have in common on the one hand and inequality that makes us unique on the other that originated in a small piece of land on the Mediterranean Sea where the best part of our consciousness comes from, has not been settled yet. (2003, p.301)

The notion of equity is thus obviously connected with the concept of difference - as its natural contradiction. In social practice, this contradiction of difference can take various forms; it is never a simple abolishment/ /elimination of difference. 
Since it has been at all possible for the notion of equity to be applied in human societies, it has always been connected with the search for sameness - i.e. an element common for all people that could be used as a basis for political or social practices/claims. In religious and late enlightenment universalism, this sameness was expressed by the notion of man - neighbor and citizen. However, most attempts at reorganizing the social world according to the principal of equity has not produced the expected results. The underlying reason was the failure to notice that the abstract notion of man assumes in the real world a tangible form of something that could be called the current standard of man - neighbor and citizen. This standard is constructed by the dominant group in its own likeness and serves the purpose of sustaining its power. As a result, the practical postulate of the equality of all people in social life - lofty and noble it may have been - would lead to taming the world's diversity, eliminating differences between people and - paradoxically - to reproducing old and generating new divisions. Depending on the social and historical context, taming can be identified as standardization, assimilation, exclusion or discrimination.

Enlightenment discourse on equity was based on ignoring differences. By no means did the proclamation of liberty, equality, brotherhood apply to all. Its author and beneficiary was - metaphorically speaking - a white, heterosexual male, a European of certain economic status.

The history of democratization - the progressing triumph of liberty and representation of the interests of the society at large - is simultaneously a history of exclusion or incomplete inclusion (Żybura, 2015, p. 150).

In the beginnings of the modern era, equity in education manifested itself first of all through compulsory schools, i.e. the same (state-organized) education for all (obviously for all at the lowest level only; admission to higher levels depended on income, social background and gender). However, this early modern education was not in the name of emancipation of the individual. As demonstrated by Gellner (1991), it was education in the interests of capitalist production (e.g. speaking the same language ensures the necessary level of communication in factories) and in the interests of the national state (patriotic education) cementing the newly invented community - the nation - which first fosters the willingness to sacrifice one's life in war. Introducing order through modern education was primarily a form of imposing a certain culture. The dialect used or indicated by the dominant group becomes the 
canonical national language, and the culture of the dominant group becomes the national culture. In fact, imposing the habitus of the privileged classes is often a violation of regional, local, ethnically different, non-European cultures. Thus, the same education for all also meant education without taking into account socioeconomic, linguistic, gender or any other differences.

The very organization of schools in the early phase of modernity is a reflection of not only the contemporary understanding of equity as superimposed cultural sameness. Its hierarchical/dichotomous organization - a fundamental division into knowledgeable experts (teachers) and nonknowledgeable students - reflects the contemporary view of the child as a potential human being /citizen, a kind of a project. Such organization excluded the formation of a democratic school community and became yet another factor of symbolic violence.

In such a situation, equal education opportunities were in the best case reduced to helping out "the poor", "the retarded" or "the socially unfit", the ethnically different, those of poor physical or mental health. However, in a setting dominated by uniform standards, such help resulted at best in paternalism and stigmatization, and - at worst - in exclusion, segregation and selection. Thus, one part of the problem was that a particular identity was imposed under the pretense of universalism, and the other part was the hierarchy and selection accompanying the education process, based on an apparently inclusive assumption: identical education for all.

The contemporary understanding of equity is marked by an alternative attitude towards difference; difference (or differences) is/are no longer sought to be eliminated. This attitude is a manifestation of a fundamentally postmodern belief in the failure of all kinds of meta-narrations that construct human subjects in an essentialist manner. It is also a manifestation of humbleness connected with the conviction that no theoretical or ethical rationale exists for indicating anyone as a subject of universalistic claims. Equity accepting differences consists in inclusion and equal treatment. Differences between humans are not unwelcome or scandalous, nor sought to be eliminated (everyone has the right to be respected). However, in social (and educational) practice the question of how to do this remains unanswered. Essentially, at the most general level the problem is whether every single difference deserves approval and if yes - how is it possible to form any kind of community? 
The absolutization of differences leads to social atomization; on the other hand, ignoring differences leads to discrimination, hierarchization, or simply injustice. It seems that both strategies - blindness to differences and uncritical acceptance of differences - are contradictory to the vision of a truly fair society. Żybura formulates this problem by asking the following question "Is non-exclusive community possible at all?" (2015, p. 157). Nevertheless, in line with Mouffe (2008) and Benhabib $(1996,2015)$ he answers affirmatively, defining certain conditions: abandoning the liberal belief that a non-antagonistic community is ideal, and embracing differences while being aware of one's own particularism, without their stigmatization (essencialization) and simultaneously without excessive celebration.

It seems that acknowledging difference cannot be reconciled with equity understood as sameness, identity or with justice defined as equal conditions for all. Understanding equity and justice as possible only when differences originating from different social positions disappear means a situation in which non-equal individuals are treated equally. Nothing can be more unequal and unfair. Equality must take into account difference, and justice must address conditions determined by different needs (Żybura, 2015, p. 165).

What does the above mean for education and how can this change in addressing difference be translated into practical solutions?

Contemporary educational discourse on equity questions the very theory of meritocracy (equal opportunities). The theory of meritocracy holds that the only inequalities that are acceptable in a contemporary society are those that result from natural differences between individuals' talents and aptitudes, as well as differences between efforts undertaken by individuals in order to achieve their goals. However, in practice it is difficult to determine what is natural and what is acquired, for instance in the form of inherited economic, social and cultural capital. Therefore, pure meritocracy is considered unfair because it leads to extreme social and economic discrepancies that result in a sense of alienation, social exclusion and pose a serious threat to social integration.

A meritocratic society in its pure form is not only unfeasible, but the concept itself is internally contradictory. In such social order the privileged can surely pass on their privileges to their children, which is against the concept of meritocracy (Giddens, 1999, p. 91). 
In essence, contemporary educational discourse on equity proclaims the idea of fairness; sometimes the rather unfortunate term positive discrimination is used to emphasize that equal does not always mean fair or that fair and just does not necessarily mean equal.

In education, the term equity refers to the principle of fairness. While it is often used interchangeably with the related principle of equality, equity encompasses a wide variety of educational models, programs, and strategies that may be considered fair, but not necessarily equal. It has been said that "equity is the process; equality is the outcome," given that equity (what is fair and just) may not, in the process of educating students, reflect strict equality (what is applied, allocated, or distributed equally). ${ }^{1}$

One of the responses to understanding equity as acceptance of difference is the concept of the "inclusive school". However, it is usually limited to a postulate demanding that common schools are open to children with disabilities. It appears that educational needs are more individualized and their catalogue should remain open. By understanding inclusion as opening up and adapting the school to diverse educational needs of students, we are addressing merely the aspect of knowledge transfer, the teacher-to-student relationship, but school is also a space for socializations and peer-to-peer relationships. Naturally, one could accept Szumski's view that inclusion, particularly if affecting students with disabilities, also has a socialization effect, because it "teaches recognition of difference and fosters co-existence of diverse individuals" (Szumski, 2006, p. 102). However, such inclusion still fails to notice those differences or differentiating features that are not connected with any special educational needs or special forms of educational support and nevertheless often are, or may be, a source of unequal treatment, exclusion or even discrimination. Therefore, this author is of the opinion that we should think simultaneously about an inclusive school and an equitable school. Inclusion and equity should function as an overall concept of formal education with reference to all and any differences on such grounds as class, race, gender, ethnicity, sexual orientation, etc. (including all possible combinations of such differences). In practice, this requires one to answer the question about how to work with difference and diversity at school.

Lynch and her colleagues (2012; Baker et al., 2004) put forward four conditions for transforming schools (formal education) into truly egalitarian

1 Equity Definition, The Glossary of Education Reform: http://edglossary.org/equity/ 
institutions: 1) equality of resources; 2) equality of respect and recognition (i.e. presentation - especially in the symbolic realm, i.e. in school texts and in language - of previously ignored, marginalized or discriminated groups or individuals); 3) equality of power - i.e. inclusion of students in decisionmaking processes at school by strengthening school democracy; 4) equality of love, care and solidarity - i.e. developing emotional intelligence of students as well as making the teacher-to-student relationship more partner-like (Lynch, 2012).

The first of the above conditions is linked to differences in the availability of economic capital determined by belonging to a particular social class. It is commonly accepted that economic capital tends to evolve into cultural and social capital and as such it remains outside the direct influence of educational activity, although the school (or rather educational policy) can to some extent compensate for differences of this kind by avoiding divisions (into schools that are better or worse, special, private, state-owned; or into groups special, advanced, make-up, etc.). The remaining conditions can be achieved by means of in-school educational activity, although their fulfillment requires radical transformations in the field of education. Such transformations would involve changing school hierarchies - relative positions of students and teachers, greater distribution of power and accountability for performance at school, greater empowerment and autonomy of children with regard to their own cognitive capabilities and reliance on their own experience. Among social functions of the school, the emancipative function of education (school) would become more important than the selective function (or even the teaching function). In a slightly simplified way, one could say that inclusion projects school as a place where the cohesion of the community is more valued than classroom achievements of individual students, and equality is the principle around which such cohesion is organized. The semantic fields of these two terms are not identical and they overlap only to some extent. When exclusion is a manifestation of inequality (whether actually or symbolically), it is simultaneously to the detriment of both equality and inclusion. However, the entire range of behaviors, attitudes or discursive acts that are associated with equality - equal status, equal treatment, equal representation in language and other symbolic forms - are rather means of inclusion, albeit it is not customary to call them that way. In other words, inclusion itself - e.g. opening schools to children with disabilities - is a precondition for equitable schools. However, efficient inclusion requires action for the sake of equity. 


\section{Equity education in research and in practice}

Equity education is a response to the lack of equality in many different areas of life. It has solid intellectual and moral foundations (equality as one of the fundamental values of a democratic society, human rights, child's rights, emancipation movements, critical theory, gender theory, queer theory, postcolonial theory, post-structuralism, etc.), but in today's world, it enjoys little political and social support.

Equality, just like inclusion, should be an axiological basis for the educational impact of contemporary schools; in this role, it should replace patriotic education (which always has nationalist origins) and any other particular concepts assuming essentialist diversification of human population translated into different kinds of hierarchies. It should also constitute a hidden curriculum behind teachers' activity, school syllabi and organizational forms.

The urgency of the need for equity education is determined not only by value shifts with regard to the very understanding of equality, but also by the changing nature of contemporary societies marked by globalization, multiculturality, democratization, individualization and emancipation of minority groups.

Due to its wide objective range and to the fact that contemporary equity discourse attracts representatives of many scholarly disciplines, ranging from philosophy, political studies, history, sociology over to law, psychology and pedagogy, as well as journalists, activists and NGOs, it can be said that equity education manifests itself in an intermittent and distributed manner in many one-off discursive acts - wherever inequality mechanisms are exposed and people are sensitized to them, and their abolishment is proposed. Such discursive acts may address various aspects of equality/ inequality. Regular equity education courses are usually part of university education and typically are focused on selected aspects of equality/ inequality, as part of specialist studies (e.g. gender studies or postcolonial studies) or specialties focusing on human rights. There are also courses in multicultural or intercultural education. Equity education is also dealt with by non-governmental organizations which usually run workshops outside formal education or organize various research projects. Thus, equity education deals with equity discourse in a variety of its forms and aspects, both critically and approvingly, both in theory and in practice. In principle, it is not confined to schools and formal education, although it is particularly interested in both of them. 
Equity education is not a proposal of a new school subject. Equity education can be understood and practiced in two ways - as a critical research practice serving the purpose of diagnosing inequalities in formal education and as a purely educational activity (classes, courses, workshops) aimed at sensitizing students to inequalities on the grounds of gender, age, disability, sexual orientation, race, class or ethnic background, etc. in educational and public discourse and empowering them with competencies required to diagnose such inequalities and to eliminate them from educational practice.

At this point, I would like to present a diagnosis of the current condition of equality in formal education in Poland, as shown by dedicated studies. As an analytical category, I will use the egalitarian school model proposed by Lynch (2012). If this model is confronted against the reality of Polish schools, it turns out that they are unequal rather than equal (Dolata, 2008).

By adequately organizing the educational system, educational authorities can ensure conditions fostering equal opportunities, which in principle means equalization of students' cultural capitals. Poland is now witnessing the end of the period (1999-2015) of making attempts at leveling out educational inequalities resulting from socioeconomic differences among students. To this end, a 9-year cycle of compulsory primary education was introduced: 6-year primary school and 3-year junior high school (gimnazjum), followed by 3-year high school (liceum) ending in state examination (matura), identical for all students. The introduction of junior high schools as a second stage of obligatory primary education, designed as district schools in urban centers, better equipped and better staffed, was aimed first of all at leveling out educational differences between urban and rural areas. Another expected pedagogical effect was the interruption of a potentially stigmatizing history of performance at school and spatial separation of students with specific behavioural issues from younger students. Although these assumptions have not been fully achieved, it is believed that the introduction of junior high schools was one of the reasons for the very good performance of Polish students in PISA rankings as compared to students from other OECD countries. $^{2}$ I wish to emphasize that in the context of equity (egalitarian) school, the PISA ranking itself is questionable due to lack of methodological clarity: (a) what does it measure - the school's overall performance or performance of individual students, their cultural capital (not necessarily

2 For the latest ranking, see http://www.bbc.com/news/business-26249042 
enhanced by schools)? (Konopczyński, 2013); (b) due to concentration on competences sought on the global labor market (but even this has not been proven) and leaving out so-called "soft" competences, team-working, empathy, care, etc. According to some critics, the PISA ranking serves the interests of the global market, it is important for state governments mostly for prestigious reasons (Śliwerski, 2016). However, the currently planned changes - reintroduction of the 8-year primary school followed by the 4-year high school - will shorten the obligatory primary education by one year and high schools once again will become more elitist. Abolishment of compulsory education for 6-year old children is another spectacular change. As a result, as previously until 2013, Poland will once again be one of few European countries where children begin primary education at the age of 7 , and compulsory kindergarten education at the age of 6 . Such decisions taken by the authorities are not inspired by researchers or experts. Six-year olds are withdrawn from schools in response to concerns of some parents (usually middle class) proclaiming the slogan "let the children enjoy their childhood". The interests of children from economically underprivileged classes have not been addressed in these solutions at all.

The postulate of equality of love, care and solidarity should be implemented inter alia by the inclusion of people with disabilities. Since 2010 it is possible in Poland to educate children with disabilities in common public schools. Szumski associates the success of inclusive education with an overall change in school education and is simultaneously skeptical about the possibility of such education in neo-liberal schools dominated by:

rivalry, strong emphasis on individual performance, which inevitably increases the differences in students' knowledge and skills. [...] Plenty of evidence demonstrates that inclusive education is at the critical point of its development. [...] The original enthusiasm of its supporters and the resistance of its fierce opponents are tapering out, thus creating a space for a certain compromise, obliterating the borders between inclusive and segregative thinking and actions. Such a condition of social practice constitutes a threat to further improvement of living conditions of people with disabilities [...]. It thwarts the opportunity for modernizing the school system as such and restoring its important mission as a public institution whose role is to ensure fair access to education for all citizens and to foster social cohesion. (2014, s. 135-137)

It seems that the equality of power is the most utopian of all conditions of an egalitarian school. Its implementation seems the most distant in time, 
although the very field of education offers convincing theoretical justification for it, as well as practical examples of successful division of power between the main school actors (e.g. Korczak's pedagogy, Summerhill, anti-pedagogy, etc.). However, there are no systemic solutions of this kind in the Polish formal education, students' councils are in no way involved in taking decisions that are truly important for students, and their critics consider them to be an equivalent of "facade democracy". Śliwerski puts it this way:

Over 20 years of my research on educational macropolicies in Poland has shown that education is first of all oriented at education about democracy and for democracy, but not in democracy. Such approach is part of the "hidden curriculum" of the Polish education system, prescribing that democracy should be taught in autocracy, preventing students, teachers and parents from authentically and actively experiencing democratic processes (and their manifestations and outcomes) at school. (2012, p. 66)

Of course there exist "islands" of democratic in-school solutions in the private sector, where attempts at introducing the principle of division (or at least distribution) of power are taken (including the most consistent and - in my opinion - the most successful implementation of school democracy in Bednarska schools group in Warsaw ${ }^{3}$ but the degree of power distribution is limited by the need to observe the law, which prescribes the structure of education, the curriculum and the forms of examination. Obviously, the very financial barrier preventing free access to such (private) schools for all students contradicts the idea of democracy and equality.

The postulate of equality of respect and recognition refers to the symbolic realm and "manifests itself in patterns of interpretation, definition and communication" (Lynch, 2012, p. 12).

On a very general level one could say that after 1989, school curricula and handbooks in Poland have been surely adjusted in one respect - all content associated with communist ideology has been removed. Such an ideological gap has not been filled with any contemporary content. The image of the contemporary world that dominates the handbooks is characteristic for a traditional, patriarchic, stable society confined by its national borders. Its structures do not change and it does not reflect the dynamism of the contemporary multicultural and globalized world, either

3 http://stronarasz.idu.edu.pl/index.php/2011-03-31-04-22-51/75-historia-demokracjiszkolnej 
in terms of the idea or in terms of the message (the most common linguistic means continue to be instruction and persuasion, rather than invitation to dialogue and discussion). Simultaneously, such a world is idealized (free of conflicts, poverty, death or violence), inbred, concentrated on the matters of its own nation and sustaining traditional hierarchies. Only the form of handbooks has been improved - better paper, better print, full-color images, sometimes multimedia.

A number of different studies investigating handbooks used in public (primary and junior high) school have reached similar conclusions. They point out to biased representations of such features as gender, ethnicity, class, race, sexuality, disability and age. In various ways, these categories are either distorted or ignored.

Gender differences are essentialized and burdened by stereotypes; most texts depict women and men in accordance with the traditional model of their social functioning, based on gender inequality: women dominate the private sphere, while men prevail in the public sphere and in the prestigious role of cultural practitioners; androcentric language is commonly used. As a matter of consequence, students learning from such handbooks are not exposed to linguistic patterns and behaviors that would be consistent with the contemporary understanding of gender equality in social life (ChomczyńskaRubacha, 2004; Pankowska, 2005; Karwatowska \& Szpyra-Kozlowska, 2010; Zamojska, 2010; Abramowicz, 2011; Chmura-Rutkowska et al., 2016).

The nation, rather than a civil community, is the community presented to students as a point of reference for their social identity. The nation is constructed in a very exclusive manner - usually as a community joined by history and martyrdom, a shared cultural tradition, the same language and Catholic religion. The nation is perceived ahistorically and organicistically (i.e. as a quasi-biological organism), which implies obliteration of all internal diversity (class, gender and other) and triggers a proneness for international rivalry and for using ethnic stereotypes in looking at Others Strangers (Zamojska, 2010; Popow, 2015). One consequence of this exclusive understanding of own community is that so-called Others (including first of all immigrants and national/ethnic minorities) are either ignored or marginalized in handbook texts; inhabitants of the global South are presented in a manner dominated by ethnocentrism, Eurocentrism, orientalism. Nondegrading depictions of Africa, Asia, Latin America, free of any colonial and racist connotations, are rare (Cywiński, 2012; Kielak \& Krawczyk, 2014; Zamojska, 2016). 
In handbook content, "persons with disabilities are either absent or marginalized" (Buchnat, Cytlak, \& Jarmużek, 2016). However, it is LGBT people that are the most invisible and ignored in handbooks and school communication, and thus they are excluded from the public sphere as a group.

It is an open question whether or not this lack of respect and recognition is transferred from handbooks to actual attitudes and behaviors at school. Studies of gender communication at school confirm sexualization of girls and a stereotypical approach to the formation of educational careers of girls and boys (Kopciewicz, 2007). The last two reports by the NGO AntiDiscrimination Education Association show evidence of stigmatization of students of low socioeconomic status and children of immigrants, as well as acts of discrimination against students whose behavior and appearance is considered non-heteronormative (including the suicidal death of a 15-year old junior high school student) (Gawlicz, Rudnicki, \& Starnawski, 2015; Chustecka, Kielak, \& Rawłuszko, 2016).

\section{Conclusions}

It would be unfortunate if - given the multitude of issues related to equality and inclusion in the society - equity education were diluted by this multitude. However, I believe that equity education cannot be associated merely with one aspect or one category of people treated unfairly. The catalogue of features on the grounds of which one can be treated unfairly is practically unlimited and in principle should remain open. Obviously, the very distinction of difference remains problematic - should all differences be accepted? This question does not have a simple answer (Kołakowski, 1990), although in a local and situational context we are capable of identifying a borderline beyond which equality/justice becomes its own contradiction.

The project of equity education understood as something that thematically integrates all possible areas of social life and social relations has at least two justifications: the fact that exclusion mechanisms are driven by similar principles - the univeralization of the structure of a particular feature marginalizes or excludes all other features. The affirmative justification is the principle of equality in social life, seen not as a pursuit of sameness, but as ensuring fair treatment for all, irrespectively of their particular features. 
Possibly, the most important theoretical problem is not the deconstruction of equality understood as sameness, but the construction of equality that accepts differences. In the field of education this principle translates into the problem of supporting minority groups without universalization or particularization; the problem of distribution of power and accountability in formal education; the problem of deconstructing exclusive structures of own community for the sake of constructing a civil community; the problem of deconstructing ethnocentrism and Eurocentrism for the sake of constructing a simply human community.

\section{References}

Abramowicz, M. (Ed.). (2011). Wielka nieobecna - o edukacji antydyskryminacyjne w systemie edukacji formalnej $w$ Polsce. Raport $z$ badań. Warszawa: Tea.

Baker, J., Lynch, K., Cantillon, S., \& Walsh, J. (2004). Equality: From theory to action. New York: Palgrave Macmillan.

BBC. (2015). Pisa tests: Top 40 for maths and reading. Retrieved from http://www.bbc.com/ news/business-26249042

Benhabib, S. (1996). Democracy and difference. Contesting the boundaries of the political. Princeton: Princeton University Press.

Benhabib, S. (2015). Prawa Innych. Przybysze, rezydenci i obywatele. Warszawa: Wydawnictwo Krytyki Politycznej.

Bourdieu, P. (2001). Reguły sztuki. Geneza i struktura pola literackiego. Kraków: Znak.

Buchnat, M., Cytlak, I., \& Jarmużek J. (2016). (Nie)pełnosprawni w społeczeństwie. 0 miejscu "Innych" w podręcznikach szkolnych. In I. Chmura-Rutkowska, M. Duda, M. Mazurek, \& A. Sołtysiak-Łuczak (Eds.), Gender w podręcznikach. Projekt badawczy. Raport. T.1. Warszawa: Fundacja Feminoteka.

Chmura-Rutkowska, I., Duda, M., Mazurek, M., \& Sołtysiak-Łuczak A. (Eds.). (2016). Gender w podręcznikach. Projekt badawczy. Raport. Warszawa: Fundacja Feminoteka.

Chomczyńska-Rubacha, M. (2004). Płeć i rodzaj w edukacji. Łódź: Wyższa Szkoła HumanistycznoEkonomiczna w Łodzi.

Chustecka, M., Kielak, E., \& Rawłuszko, M. (2016). Edukacja antydyskryminacyjna. Ostatni dzwonek! O deficytach systemu edukacji formalnej wobszarze przeciwdziałania dyskryminacji i przemocy motywowanej uprzedzeniami. Raport z badań. Warszawa: Towarzystwo Edukacji Antydyskryminacyjnej.

Cywiński, P. (2012). "W pustyni i w puszczy" nie dla dzieci. Kontakt. Dwutygodnik internetowy, 2012(20). Retrieved from http://magazynkontakt.pl/w-pustyni-i-w-puszczy-nie-dla-dzieci. html

Dolata R. (2008). Szkoła-segregacja-nierówności. Warszawa: Wyd. Uniwersytetu Warszawskiego.

Gawlicz, K., Rudnicki, P., \& Starnawski M. (Eds.). (2015). Dyskryminacja w szkole - obecność nieusprawiedliwiona. O budowaniu edukacji antydyskryminacyjnej $w$ systemie edukacji formalnejw Polsce. Raportz badań. Warszawa: Towarzystwo Edukacji Antydyskryminacyjnej. 
Gellner, E. (1991). Narody i nacjonalizm. Warszawa: PIW.

Giddens, A. (1999). Trzecia droga. Odnowa socjaldemokracji. Warszawa: Książka i Wiedza.

Howarth, D. (2008). Dyskurs. Warszawa: Oficyna Naukowa.

Karwatowska, M., \& Szpyra-Kozłowska, J. (2010). Lingwistyka płci. Ona i on w języku polskim. Lublin: Wydawnictwo UMCS.

Kielak, E., \& Krawczyk, E. (Eds.). (2014). Edukacja globalna w podręcznikach do geografii. Raport z analizy wybranych podręczników szkolnych pod kątem założeń edukacji globalnej. Retrieved from http://zagranica.org.pl/publikacje/edukacja-globalna/edukacja-globalnaw-podrecznikach-do-geografii-raport-z-analizy

Kołakowski, L. (1990). Samozatrucie otwartego społeczeństwa. In L. Kołakowski (Ed.), Cywilizacja na ławie oskarżonych (p. 173). Warszawa: Res Publica.

Konopczyński, F. (2013). PISA 2012: Studzenie entuzjazmu. Retrieved from http://publica.pl/ teksty/studzenieentuzjazmu-40647.html

Kopciewicz, L. (2007). Rodzaj i edukacja. Studium fenomenograficzne z zastosowaniem teorii społecznej Pierre'a Bourdieu. Wrocław: DSW.

Lynch, K. (2012). Oświata jako miejsce zmiany: ramy promocji równości i przeciwdziałania niesprawiedliwości. In G. Mazurkiewicz (Ed.), Jakość edukacji. Różnorodne perspektywy (pp. 29-64). Kraków: Wydawnictwo Uniwersytetu Jagiellońskiego.

Mouffe, C. (2008). Polityczność. Przewodnik Krytyki Politycznej. Warszawa: Wydawnictwo Krytyki Politycznej.

Olszewski, W. (2011). Historia demokracji szkolnej. Retrieved from http://stronarasz.idu.edu. pl/index.php/2011-03-31-04-22-51/75-historia-demokracji-szkolnej

Pankowska, D. (2005). Wychowanie a role płciowe. Gdańsk: GWP.

Popow, M. (2015). Kategoria narodu w dyskursie edukacyjnym. Analiza procesów konstruowania tożsamości w podręcznikach szkolnych. Poznań: Wyd. UAM.

Savater, F. (2003). Mój słownik filozoficzny. Poznań: AXIS.

Stasiuk, K. (2003). Krytyka kultury jako krytyka komunikacji. Pomiędzy działaniem komunikacyjnym, dyskursem a kulturq masową. Wrocław: Wydawnictwo Uniwersytetu Wrocławskiego.

Szumski, G. (2006). Edukacja inkluzyjna - geneza,istota, perspektywy. Kwartalnik Pedagogiczny, 99(1), 93-14.

Szumski, G. (2014). Edukacja włączająca - niedokończony project. Ruch pedagogiczny, 85(4), 127-140.

Śliwerski, B. (2012). Dokąd zmierza polska edukacja? Neodidagmata, 2011-2012(33/34), 65-76.

Śliwerski, B. (2016). Krytycznie o metodologicznych przesłankach udziału naukowców w Międzynarodowym Programie PISA/OECD. Studia Edukacyjne, 2016(38), 21-42.

Zamojska, E. (2010). Równość w kontekstach edukacyjnych. Wybrane aspekty równości w polskich i czeskich podręcznikach szkolnych. Poznań: Wyd. UAM.

Zamojska, E. (2016). Konstrukcja Innego/Innej w podręcznikach szkolnych. In I. ChmuraRutkowska, M. Duda, M. Mazurek, \& A. Sołtysiak-Łuczak (Eds.), Gender w podręcznikach. Projekt badawczy. Raport. T.1 (pp. 259-268). Warszawa: Fundacja Feminoteka.

Żybura, W. (2015). Wspólnota demokratyczna a wykluczenie. Zoon Politikon, 2015(6), 147-173. 


\title{
Author
}

prof. UAM dr hab. Eva Zamojska, Uniwersytet im. Adama Mickiewicza w Poznaniu, Wydział Studiów Edukacyjnych, Zakład Pedagogicznych Problemów Młodzieży, ul. Szamarzewskiego 89 (bud. D), 60-568 Poznań, Poland, e-mail: zameva@amu.edu.pl

\section{Rovnost a různost ve vzdělávání. Teoretická a praktické problémy spravedlnosti vzdělávání - polský př́íklad}

\begin{abstract}
Abstrakt: Studie si klade za cíl zamyslet se nad současným chápáním rovnosti a různosti ve vzdělávání a na základě diskuse výběru odborných textů představit klíčové teoretické a praktické problémy ovlivňující spravedlnost vzdělávání v Polsku. Každý projekt zaměřený na spravedlnost ve vzdělávání musí čelit dialektice rovnosti a různosti ve vzdělávání. $\mathrm{V}$ historické perspektivě lze jasně vysledovat evoluci modernistického pojetí rovnosti ve vzdělávání. Základem této evoluce byla změna v chápání různosti: od chápání rovnosti jako stejnosti a důrazu na standardizované praktiky ve vzdělávání (jednotná škola; ačkoliv byla ovlivněna myšlenkou národa - Gellner - a skrytým genderovým, třídním, rasovým a etnickým dělením), přes segregaci a selekci na základě různých rozdílů, až po dnešní chápání rovnosti jako přijímání rozdílů a snahy o rovnováhu mezi citlivostí k rozdílům a spravedlivým přístupem ke všem bez ohledu na tyto rozdíly. Toto poslední pojetí dialektiky mezi rovností a růzností tvoří základ spravedlivého vzdělávání, které je podle autorky jedním z prostředků sociální inkluze. Je ale potřeba diskutovat tři překážky efektivní implementace této myšlenky. Zaprvé, vzdělávání jako oblast (Bourdieu) má specifický charakter. Je těžké sladit nutnost přetvářet lidi v souladu s přednastavenými cíli, testování a hierarchickou strukturu samotného procesu vzdělávání s výše uvedeným chápáním rovnosti. Dalším problémem je neoliberální logika trhu, která prohlubuje třídní rozdíly ve struktuře vzdělávacího systému (tj. rozdělení na státní a soukromé školy) a vytváří rozdíly mezi státními školami („lepší“ a „horší“ školy), a tak vnucuje všem účastníkům vzdělávání, kteří se snažit naplnit dané cíle, rivalitu a extrémní individualizaci (neboli soutěž kulturního kapitálu). Třetím problémem je nesoulad mezi obsahem kurikula a učebnic a diskursem rovnosti. Tento problém je v naší studii ilustrován na př́ikladu Polska a tamějších výzkumů obsahu učebnic.
\end{abstract}

Klíčová slova: rovnost, různost, spravedlnost vzdělávání 